Article

\title{
The Intrinsic Value of an Enterprise Determined by Means of the FCFE Tool
}

\author{
Veronika Jezkova, Zuzana Rowland, Veronika Machova* ${ }^{\mathbb{D}}$ and Jan Hejda \\ Institute of Technology and Business, School of Expertness and Valuation, Okruzni 517/10, \\ 37001 Ceske Budejovice, Czech Republic; 18375@mail.vstecb.cz (V.J.); \\ rowland@mail.vstecb.cz (Z.R.); hejda@mail.vstecb.cz (J.H.) \\ * Correspondence: machova@mail.vstecb.cz; Tel.: +778-714-680
}

Received: 14 September 2020; Accepted: 21 October 2020; Published: 26 October 2020

check for updates

\begin{abstract}
This paper deals with the determination of the intrinsic value of the company Seznam.cz, a.s. using discounted cash flow. Specifically, it is concerned with determining the value of the business from the perspective of the company's shareholders. The Free Cash Flow to Equity (FCFE) method is chosen for analysis and determination of the value. According to this method, the specific FCFE values are discovered. However, the enterprise value must also be analyzed on the basis of other key indicators, such as financial leverage, the Capital Asset Pricing Model (CAPM) method, or the net present and future value of the FCFE. This is especially important so that the results can be put into mutual relations and a sufficient representative value of the FCFE results can be achieved. Input values stem from the company's annual reports. From the results of the mentioned methods and indicators, it was found that the value of the FCFE is quite high, which means that the capital used is used appropriately. Based on the result of the continuing value of the FCFE, it can be said that the company's intrinsic value is at a very good level.
\end{abstract}

Keywords: company's intrinsic value; free cash flow; financial leverage; CAPM; FCFE

\section{Introduction}

Determining the value of a company is one of the most frequent and intensively used but, at the same time, relatively complicated operations, and it can be viewed from a number of perspectives. The problem of corporate valuation and corporate investment is addressed, for example, by Magni [1], who describes many realistic approaches to corporate valuation and corporate investment. The issue of valuation is also viewed from an accounting perspective on the basis of financial statements. Valuation using book value is specified by the Accounting Act and provides an initial picture of the current value of a company and of its individual assets in particular [2]. However, from the point of view of management, potential investors, or credit companies, the substantive value is also important, as it may have a higher information value from their perspective. For example, they may focus on net assets [3] or the revenue approach, such as discounted cash flows [4]. It is exactly this principle, or the Discounted Cash Flow (DCF) method, that is one of the most effective ones out of the methods listed above. The issue of DCF has several basic areas, among which FCFF (Free Cash Flow to Firm) and FCFE (Free Cash Flow to Equity) can be included. In determining the intrinsic value of the company, it is appropriate to use the Free Cash Flow to Equity model, hereinafter referred to as the FCFE, which consists in determining free financial means for owners reduced by all liabilities to creditors. The abbreviation FCFE stands for free cash flow to equity, i.e., for shareholders. In essence, it is a cash flow that can be withdrawn from the enterprise and transferred to the owner without the enterprise being adversely affected in any way. FCF, or free cash flow, is the cash flow generated by the basic operations of a business after deducting investments in new 
capital [5]. CFE, or cash flow to equity, is understood as a cash flow that is withdrawn from the company and passed on to the owner (shareholder). It no longer matters whether the company as such will be endangered in its activities [6]. In the case of FCFE, it is essential to ensure that what is taken from the company can be taken indeed (reproduction of fixed assets must be preserved; material and sufficient liquidity must be ensured). In the second case, we withdraw funds based on the decision of the general meeting of the company, and we do not decide whether or not the company will continue to operate (there can really only be paid dividends). FCFE does not necessarily have to be distributed to shareholders-it can only be removed from the company if necessary (CFE is fully distributed). At the same time, FCFE is almost never fully distributed to owners. This does not make much sense (especially if the company can evaluate the funds). According to Mielcarz and Mlinarič [7], the FCFE model is one of the three most important methods for valuing a company, while they also analyze the risks of individual methods, drawing particular attention to the danger of excessive investment. For example, Barealey, Myers, and Allen [8] present methods for determining the Net Present Value of specific assets of valued companies. The use of this model is most suitable for companies that are referred to as Going Concerns [9]. These are organizations that are in a stage of maturity, and it can be assumed that they will maintain their stability for the next period. The value of a company, or the intrinsic value of a share, is important for shareholders who make decisions about potential investments [10]. The very possibility of a potential investment is increasing in the case of so-called Green Companies, which have received this label in terms of the environmental sustainability of their activities. Investors in these companies are often referred to as green investors [11]. The use of this model is crucial for making strategic decisions, mainly because the free cash flow expresses the resulting amount that will remain available to the company after a reduction in capital expenditures, and the organization can freely dispose of it. The company should allocate these free funds in the most appropriate way. On the other hand, Zurita, Castillo, and Niño [12] point out the need to take into account the legislative and fiscal conditions of the region, where the problem is, for example, compatibility and limited reporting of financial statements, which pose a significant risk from the assessor's point of view [13]. From the point of view of the EU, according to Kasych, Vochozka, and Yakovenko [14], it is necessary to diagnose states in terms of the stability of companies operating in them. This also helps to respond to a forthcoming economic crisis early, and can thus minimize the negative consequences for individual companies.

At the same time, it is necessary to take into account the dynamics of economic and industrial development, where the value of companies increasingly reflects state plans, such as "Industry 4.0", which determine the futures of the relevant fields $[15,16]$. Nevertheless, the FCFE method belongs, according to Dagnino et al. [17], among the basic sources for managerial approaches and evaluations from the perspective of potential investors.

The resulting FCFE values can, therefore, be applied to define the competitiveness of an assessed company as well as its potential.

In our article, we address the FCFE option-we determine the value of a company based on the fact that part of its capital can be taken from it (while continuing its other activities).

The aim of the paper is to define the intrinsic value of a particular company using the FCFE model from the perspective of the equity owner and to evaluate the advantages and disadvantages of using this tool in the case of a specific Czech company.

\section{Literature Review}

Company evaluation is one of the most frequently described and mentioned research questions in the economic literature. According to Anwer et al. [18], the decision about capital entry into the company can be, in addition to a strict investment approach, based on a number of factors, such as personal preferences. According to To, Chau, and Kan [19], the decisive factors for the value of a company are represented by the structure of dependence on business, the dominance of company value, the dynamics of innovation, and their agility. The importance of corporate accelerators 
is then emphasized by Lange and Johnston [20], who subsequently evaluate the time value factor for investors [21]. Another example is the valuation of a company using the objectivized value of the company determined on the basis of the value of the company's small assets [22].

An important phenomenon on which the current research of companies' value is focused is the influence of the pseudo-market environment. In this case, criteria such as the company's connection to sustainability or its position in the social network environment enter into the assessment process [23,24]. Cui et al. [25] use the Decision Testing and Evaluation Laboratory (DEMATEL) method to identify these risks and benefits. Hybrid organizational forms combining commercial and social institutional logic are being explored in order to understand newly set value movers and their impact on society [26]. Based on systems theory, they explain the high contribution of social media analysts to the value of a company and the differences in their effects on small, medium, and, subsequently, large companies [27]. According to Zhang et al. [28], structural, cognitive, and relational links based on social media are an important mechanism for improving the overall performance of a company. Dong, Wen, and Liu [29] present an example of the sustainability of a Chinese bank's business. They modeled the sustainability of a particular banking institution in the case that this institution begins to discriminate against certain clients concerning credit. This strategy may temporarily increase its economic performance, but this situation may not be sustainable for survival on the financial market. It would also disrupt the entire banking market, which could lead to its gradual destabilization. According to Tiba and Frikh [30], one of the foundations of business sustainability is represented primarily by employees, especially in developing countries. When formulating a business model of a given company with regard to its subsequent sustainability, it is important to take into account all internal and external factors that may influence this increasingly important parameter, and also to implement them in overall internal company analyses [31].

Kuo [32] focuses on the evaluation of prices of companies listed on the Taiwan Stock Exchange using predictive regression methods, according to which the vector of the error correction model shows the best results. On the contrary, they use the net asset value method [33] to assess the fiscal health of the state or the state companies, according to which this model has an optimal information value beyond its basic accounting interpretation. Erauskin and Gardeazabal [34] arrive at the same result, assessing the optimal level of foreign net assets and domestic wealth at the state level in relation to economic performance. They focus on differences in the valuation of companies innovating services in the Business to Business (B2B) and Business to Consumer (B2C) segments [35], where, according to them, these steps have a significantly greater positive impact on the value if a company focuses on the first of the mentioned sectors.

From this point of view, cash flow discounting methods belong among the more traditional-but proven-methods. They do not only have to be used to value a whole society. According to Chang et al. [36], they provide, for example, the optimal possibility of determining the selling price of a product. Lilford, Maybee, and Packey [37] offer solutions to problems related to the stationarity of discount rates used in discounting cash flows. They solved the problem of data instability using a nonlinear programming optimization model [38]. Subsequently, Bian et al. [39] present a dynamic model of discounted cash flows in combination with the WCR (working capital) model. The analysis of discounted financial flows within the newly modeled supply-retail customer chain was also used by Li et al. [40] and Pless et al. [41] to identify the optimal model for investing in a functional energy mix in the United States. Drobetz, Janzen, and Meier [42] focused on differences in the allocation and discounting of cash flows, revealing significant differences between private and more sensitive public companies in the Western European region. They focused their attention on fair value discounting of cash flows in the analysis of the real estate market in Spain, taking into account the specifics of Spanish valuation processes [43]. In itself, this is not accepted without reservations, as it is not possible to express the real value according to some authors. This is also confirmed by Tsuji [44], according to whom the analysis according to DCF (discounted cash flow) is insufficient. According to him, the DCF model expresses only the expected value in the future and not the 
actual value. Prusak [45] disagreed with this view, arguing that there is no single appropriate method to determine only one enterprise's value. The resulting value of a company is the average of several values. This problem with many valuation methods was also encountered by Turcas et al. [46], according to whom the final choice of the most suitable valuation method depends on the choice of the potential investor method. However, the investor themselves can also decide on the basis of this information whether the company they invest in is economically sustainable even if it is forced to introduce some innovations in order to preserve its competitive ability in the constantly evolving market. Jin, Navare, and Lynch [47] conducted a global survey of the extent to which companies forced to take innovative steps are sustainable, especially shortly after these changes. Along with these innovations, the corporate culture must also undergo innovation, which can have fatal consequences in some cases. Bodhanwala and Bodhanwala [48] found out that companies with sustainable development strategies are more profitable. According to Sroufe and Gopalakrish [49], social sustainability performance is also increasing.

There are a number of outputs to the basic issue of FCFE (Free Cash Flow to Equity); however, there are not enough scientific papers, which may be the result of both the relatively frequent use of other methods and the underdeveloped research. This may be due to the existence of several methods by means of which the value of a company can be expressed [50].

According to Almabekova, Kuzmich, and Antosik [51], the right choice of method is also a deciding factor for owners who have to assess the enterprise value in times of an economic crisis. Furthermore, it is necessary for the owners of the company to express the value in the case of mergers with other companies. Toll and Hering dealt with the method of expressing the value according to the owners when merging companies [52]. Lorenc and Kustra [53] discuss the expression of value for owners using FCFE, and they describe the methodology that is best used in the analysis. Suhanda, Hidayat, and Firmansyah [54] use the same method of determining the value of a company using FCFE.

The main goal of an organization is primarily to constantly increase the value of the company along with increasing value for the shareholders themselves. An increase in dividend payout is also important for them [55]. However, the payment of dividends should not be the sole purpose of using free funds, as this can cause problems between managers and shareholders in the company. Both parties view the company's objectives in a different way [56,57]. According to Nekhili et al. [58], it is also essential to analyze the interrelationship between profit and free cash. Nobanee and Abraham [59] and Bonazzi, Camanzi, and Iotti [60] have also addressed this interconnectedness. According to Nozari [61], free funds are also affected by the amount of leverage. Georgios and Chris [62] see several advantages in the FCFE methodology. According to them, the FCFE method views the company as a living organism regardless of the amount of property. The FCFE method analyzes future expected returns, not the past ones. Significantly, the FCFE method takes into account not only taxation, but also the market situation, which has a major impact on the valuation result. The most appropriate use of the FCFE method is to define the values of firms in the banking or financial sector [63]. Georgios and Chris [62], on the other hand, mention that the use of the FCFE method for the evaluation of private companies has no informative value, as this method does not provide correct data compared to other more appropriate methods. The FCFE method is more appropriate for evaluating public companies. Li, Minor, Wang, and Yu [64] also add that the value of a company is also influenced by its corporate social responsibility (CSR). CSR can represent a surprisingly positive income for companies. According to the findings, CSR has several major consequences for a particular company. CSR contributes positively to a short-term increase in self-performance. Annual CSR rankings can provide a correction for the market value of the company's intangible assets. Usman [65] confirmed the link between CSR and the sustainability of the company based on a logical regression of the quarterly data provided voluntarily by Indian companies. Compared to other random indicators of companies that show mixed results, the link between CSR and the company's sustainability is clear. Li, Morris, and Young [66] analyzed 3400 publications that provided information on companies in the time period 1994-2008. Based on this analysis, they found that the frequency with which a particular 
company appears in these media leads to its visibility, which has a positive effect on its CSR. Due to their size, larger companies are also more likely to be visible and, thus, better able to achieve higher CSR ratings. According to Hur, Moon, and Kim [67], the company's CSR also has a significant impact on its potential customers. A positive relationship between CSR and C-C (Customer-Company) identification was also demonstrated. Potential customers of companies learn about their positive CSR through all multimedia communication channels [68]. Beck, Frost, and Jones [69] also found a link between a company's CSR and its financial performance based on a sample of companies from several countries on different continents. This suggests that CSR is of global importance to companies in terms of their financial performance.

As already mentioned, many methods can be used to provide an analysis of a company's value. It is necessary to first assess each company in order to choose the most appropriate method. We analyze the company, for example, in terms of the sector in which it is located, or according to the stability, which affects possible mergers with other companies. Not only the result of the FCFE is important, but also, above all, the interconnection of the FCFE with other important indicators for the company. It can be, for example, the amount of financial leverage or profit. Finding out the result of the FCFE is not enough; it is necessary to analyze in detail why, according to the indicator, the funds are of such an amount, and what exactly this may mean for shareholders. However, the value of an enterprise also evolves over time. Vochozka, Stehel, and Rowland, for example, dealt with this problem, mainly with the monitoring of the development of a company's value over time [70].

\section{Materials and Methods}

The actual performance of the analysis using the FCFE model consists in valuing the company through the analysis of cash flow statements. The necessary economic data for the input for the FCFE analysis are the cash flow statements for a certain period of time (usually a year), which can be found in the company's annual reports containing their financial statements. The business entity Seznam.cz, a.s. was chosen as a subject of an FCFE analysis case study. The source of data will, therefore, be the company's financial statements from the period from 2016 to 2019. The characteristics of the input data are given in Table 1.

Table 1. Input values obtained from the company's financial statements.

\begin{tabular}{ccccc}
\hline Quantities & $\mathbf{2 0 1 6}$ & $\mathbf{2 0 1 7}$ & $\mathbf{2 0 1 8}$ & $\mathbf{2 0 1 9}$ \\
\hline Net profit (mil. CZK) & $1,106,790$ & $1,337,709$ & $1,313,642$ & $1,182,362$ \\
Amortization (mil. CZK) & 242,981 & 270,582 & 266,360 & 300,076 \\
Investment costs (mil. CZK) & $-453,837$ & $-174,628$ & $-326,592$ & $-310,031$ \\
Change of working capital (mil. CZK) & $-37,858$ & $-98,782$ & -483 & 32,272 \\
Debt repayments (mil. CZK) & $-142,510$ & $-147,334$ & $-147,333$ & 0 \\
New loans (mil. CZK) & 294,667 & 147,333 & 0 & 0 \\
Number of stocks issues (pieces) & 3720 & 2604 & 2604 & 2604 \\
Overall assets (mil. CZK) & $2,067,068$ & $2,410,742$ & $2,065,060$ & $1,976,843$ \\
Own resources (mil. CZK) & 836,414 & $1,592,452$ & $1,322,741$ & $1,190,452$ \\
\hline
\end{tabular}

The basic indicators that can be found in the income statement are net profit (placement ${ }^{* * *}$ ) and amortization (placement E. 1. 1.). The indicators that can be found in the balance sheet are new loans (placements C. I. 2. and C. II. 2.), assets (placements A. + B. + C. + D.), and the company's own funds (A.). The cash flow statement includes capital expenditures (location B. 1.), change in working capital (location A. 2.), and debt repayments (location C. 1.). The last important indicator is the number of shares issued, about which the information can be found in the general information in the financial statements under Chapter 7-Equity.

First, it is necessary to calculate the FCFE value for each year. The calculation is based on net profit, which is subsequently adjusted for amortization, capital expenditures, changes in working capital, debt repayments, and newly issued debts. Amortization and newly issued debts are added to net profit. 
Other indicators are subtracted. After performing this calculation, the value of the amount of free funds for owners for individual years is obtained. In order to determine the intrinsic value of the company, it is necessary to calculate the share of FCFE and the number of shares issued. This step determines the intrinsic value of the business. This intrinsic value, which is represented by the FCFE per share, can be compared to the market price of the share. By evaluating this result, the analyst can determine whether the company's shares are undervalued or overvalued. The functioning and activities of analysts are of great importance in this area.

Comparison with other indicators that may affect the resulting FCFE is also important for assessing the results-for example, the assessment of a company in terms of the amount of financial leverage, which consists of the share of total assets and the company's own resources.

Determining the FCFE value alone is not sufficient; it is also necessary to determine the discounted and future FCFE values. To determine both values, it is necessary to know the discount rate of alternative costs of equity, which can be determined using the Capital Asset Pricing Model (CAPM) method. The CAPM calculation requires such quantities as the nominal risk-free rate $\left(r_{f}\right)$, which will be added to the multiple of the beta $(\beta)$, and the risk premium $\left(r_{m}-r_{f}\right)$. For the nominal risk-free rate $\left(r_{f}\right)$, the values of ten-year government bonds for individual years as of the last day of the given year were used. The beta value input was obtained from the Damodaran website, where the data are stored in the betas by sector archive. Due to the company's activity field, the Computer Services sector was selected, and the value according to the beta column was selected. The value of the risk premium, which is $7.12 \%$ (09.05.2020), was also obtained from this page.

This calculation yields a CAPM value called "re", which serves as an input to determine the current and future FCFE values. It is also necessary to determine the growth constant for the future value. For the purposes of this work, GDP growth in the Czech Republic was chosen.

\section{Results}

Based on the previously established methodology, the following results were found (Table 2). First, the FCFE value was quantified.

Table 2. The final Free Cash Flow to Equity (FCFE) value.

\begin{tabular}{ccccc}
\hline Required Quantities & $\mathbf{2 0 1 6}$ & $\mathbf{2 0 1 7}$ & $\mathbf{2 0 1 8}$ & $\mathbf{2 0 1 9}$ \\
\hline Net profit & $1,106,790$ & $1,337,709$ & $1,313,642$ & $1,182,362$ \\
Amortization & 242,981 & 270,582 & 266,360 & 300,076 \\
Capital expenditures & $-453,837$ & $-174,628$ & $-326,592$ & $-310,031$ \\
Change of working capital & $-37,858$ & $-98,782$ & -483 & 32,272 \\
Debt repayments & $-142,510$ & $-147,334$ & $-147,333$ & 0 \\
New loans & 294,667 & 147,333 & 0 & 0 \\
FCFE (in CZK) & $\mathbf{1 , 0 1 0 , 2 3 3}$ & $\mathbf{1 , 3 3 4 , 8 8 0}$ & $\mathbf{1 , 1 0 5 , 5 9 4}$ & $\mathbf{1 , 2 0 4 , 6 7 9}$ \\
\hline
\end{tabular}

When comparing these three calculations, it is obvious at first glance that the volume of free funds for owners increased rapidly (by $32.14 \%$ ), and then there was a significant decrease (by $20.74 \%$ ). In order to determine the value of the company, it is necessary to determine the intrinsic value of the share. The intrinsic value is determined by the ratio of the FCFE and the number of shares issued during the period (Table 3).

Table 3. The final intrinsic value.

\begin{tabular}{ccccc}
\hline Required Quantities & $\mathbf{2 0 1 6}$ & $\mathbf{2 0 1 7}$ & $\mathbf{2 0 1 8}$ & $\mathbf{2 0 1 9}$ \\
\hline FCFE & $1,010,233$ & $1,334,880$ & $1,105,594$ & $1,204,679$ \\
Number of shares issued & 3720 & 2604 & 2604 & 2604 \\
FCFE for one share (in CZK) & $\mathbf{2 7 1 . 5 7}$ & $\mathbf{5 1 2 . 6 3}$ & $\mathbf{4 2 4 . 5 8}$ & $\mathbf{4 6 2 . 6 3}$ \\
\hline
\end{tabular}


The same development can be seen when comparing the internal value of the action per issued piece according to the FCFE analysis.

An important indicator is also financial leverage, which is calculated as the ratio of total assets and the company's own resources (Table 4).

Table 4. The final financial leverage value.

\begin{tabular}{ccccc}
\hline Required Quantities & $\mathbf{2 0 1 6}$ & $\mathbf{2 0 1 7}$ & $\mathbf{2 0 1 8}$ & $\mathbf{2 0 1 9}$ \\
\hline Total assets & $2,067,068$ & $2,410,742$ & $2,065,060$ & $1,976,843$ \\
Own resources & 836,414 & $1,592,452$ & $1,322,741$ & $1,190,452$ \\
Financial leverage & $\mathbf{2 . 4 7}$ & $\mathbf{1 . 5 1}$ & $\mathbf{1 . 5 6}$ & $\mathbf{1 . 6 6}$ \\
\hline
\end{tabular}

The resulting value of financial leverage shows that the value decreased rapidly between 2016 and 2017. In 2018, it was approximately at the same level as in 2017.

Given the fact that the FCFE analysis is based on discounted cash flow, it is necessary to determine the net present value. To determine it, it is necessary to know the discount rate of alternative costs of equity, which can be determined using the Capital Asset Pricing Model (CAPM) method (Table 5).

Table 5. The final Capital Asset Pricing Model (CAPM) values for the respective years.

\begin{tabular}{ccccc}
\hline Required Quantities & $\mathbf{4}$ & Value re for the Respective Years \\
& $\mathbf{2 0 1 6}$ & $\mathbf{2 0 1 7}$ & $\mathbf{2 0 1 8}$ & $\mathbf{2 0 1 9}$ \\
\hline Nominal risk-free rate $\mathrm{r}_{\mathrm{f}}$ & 0.53 & 1.5 & 2.1 & 1.51 \\
Coefficient $\beta$ & 1.2 & 1.2 & 1.2 & 1.2 \\
Risk premium $\left(\mathrm{r}_{\mathrm{m}}-\mathrm{r}_{\mathrm{f}}\right)$ & 7.12 & 7.12 & 7.12 & 7.12 \\
CAPM re value (in \%) & $\mathbf{9 . 0 7 4}$ & $\mathbf{1 0 . 0 4 4}$ & $\mathbf{1 0 . 6 4 4}$ & $\mathbf{1 0 . 0 5 4}$ \\
\hline
\end{tabular}

The next step is to calculate the net present value (Table 6). The input for this calculation is again the value of the FCFE, as well as the discount rate from the CAPM.

Table 6. The final net present value.

\begin{tabular}{ccccc}
\hline Required Quantities & $\mathbf{2 0 1 6}$ & $\mathbf{2 0 1 7}$ & $\mathbf{2 0 1 8}$ & $\mathbf{2 0 1 9}$ \\
\hline FCFE & $1,010,233$ & $1,334,880$ & $1,105,594$ & $1,204,679$ \\
CAPM re value & 0.09074 & 0.10044 & 0.10644 & 0.10054 \\
Net present value (in CZK) & & $\mathbf{4 , 0 3 0 , 1 4 5 . 0 9}$ & & \\
\hline
\end{tabular}

It is also important to determine the future value of the FCFE for 2020 (Table 7). The growth constant represents GDP growth in 2020.

Table 7. The final future FCFE value.

\begin{tabular}{cc}
\hline \multicolumn{2}{c}{ Required Quantities } \\
\hline FCFE 2019 & $1,204,679$ \\
CAPM 2019 re value & 0.10054 \\
Growth constant g & 0.024 \\
Future FCFE 2020 value (in CZK) & $\mathbf{1 5 , 7 3 9 , 2 0 8 . 2 6}$ \\
\hline
\end{tabular}

\section{Discussion}

Based on the results for financial leverage, it can be stated that this value stabilized between 2017 and 2018. This means that the company achieved a stabilized financing structure. Given the fact that the explanatory power of the Free Cash Flow to Equity model is more accurate if the company has a stable funding structure, this indicates that this model was used appropriately. According to Morri and 
Artegiana [71], the capital structure may be affected in specific countries by government regulations that do not allow companies to achieve high leverage due to the optimization of the capital structure.

The high sensitivity of the results is mainly due to the level of the discount rate, which depends on the stability of the country's economy. Another factor is represented by the large fluctuations in the amount of financial leverage, which can skew the final value of the FCFE for individual years and may lead to a lower informative value of the results based on this analysis. Newly obtained loans also have a large effect on the resulting value of the FCFE, which can skew the results.

With expertise, this problem can be solved-for example, through innovated network graphs [72], where it is necessary to take into account the prediction of future profits of the company. The market valuation of the company also represents an issue in relation to market development and the possible consideration of its fundamentals. These factors point out, for example, the risks associated with the discrepancy between the valuation of financial methods and the value of the fundamentals [73].

At the same time, intangible assets must also be taken into consideration, both for fundamentally based companies addressing issues such as emissions and current and future regulations [74] as well as for companies operating in a specifically European environment [75]. The valuation of technological companies or companies dependent on Internet business is one of the biggest challenges of current research. As pointed out by Tarifa-Fernández, Sánchez-Pérez, and Cruz-Rambaud [76], the high flexibility associated with these technologies requires the use of appropriate tools that can properly assess both the potential return on investment and the level of risk.

Using the FCFE analysis, values for the years 2016 to 2019 were obtained. It is clear that the resulting values of free funds for owners have a fluctuating trend. This is mainly due to the value of new loans, which reached zero in the last mentioned year. The second significant influencing factor is represented by the values of capital expenditures, which differed significantly between years. These two items then cause the given volatility. The average value for owners is 1,163,847 CZK. This value can also be called net trading assets for shareholders. Shareholders can then decide whether these funds will be retained in the company and used for further business or whether these funds will be paid out through dividends or certain profit shares. If the company does not try to pay dividends, it is to maintain their stability. Another reason for retaining financial means may be due to planned capital expenditures in the future. This phenomenon can also be observed in the results above. In 2017, it is possible to observe an increase in FCFE by $32.14 \%$, and then the FCFE decreased significantly by $20.74 \%$. With the same comparison of the volume of capital expenditures, it is clear that there was a huge increase of $87.02 \%$. It is, therefore, clear that the company kept a larger amount of funds in 2017 due to its larger planned investments in 2018. Therefore, the financial means played the role of a certain financial reserve, which may be of particular interest to managers in the company who are in charge of investment activities or trying to hold reserves for unfavorable periods.

The resulting FCFE value can also be used to determine the intrinsic value of the FCFE for the number of shares issued from the shareholder's perspective. This value represents how much free cash is available per share. This quantity also serves as a basis for calculating the actual value of the share, which can then be compared with the market price of the share and makes it possible to determine whether the share is undervalued or overvalued. This finding provides an opportunity for further research.

An important element of the calculations was the determination of the CAPM value, which served as an input for determining the net present value and the continuing value of the FCFE. The result of 4,030,145.09 CKZ represents the true intrinsic value that the company has with respect to the time factor, as all three mentioned years were considered. The discount rate given by the result of the CAPM method was also used in this calculation. This discount rate was also used to calculate the continuing value of the FCFE. The result of the continuing value determined by the yield method (discounted FCFE for the last four years) is 15,739,208.26 CZK. This value is determined as perpetuity, the result of which is the price of the company, which indicates whether the company will continue to operate, meaning that it does not show signs of bankruptcy. 


\section{Conclusions}

The main aim of this paper was to determine the intrinsic value of the company Seznam, a.s. using the FCFE method. The FCFE method was used adequately. This paper presented a valuation method designed for sales purposes.

This goal was fulfilled. First, it was necessary to use this method to determine free cash for shareholders for each year of the time period 2016-2019. Subsequently, it was necessary to determine the discount factor using the CAPM model. After that, the resulting intrinsic value of the company could be calculated with the final value of 4,030,145.09 CZK. The total value of the organization lies in the sum of the intrinsic value in the first phase of the calculation and the ongoing value. Another advantage is the availability of source data, which are needed for this analysis. Determining the value of the company is also important from the point of view of managers because, on the basis of these results, they can adjust or even significantly change their decisions, leading to an increase in the value of the company. For this purpose, other methodological approaches analyzed by Kasych and Vochozka [77] are also available. Moreover, further recommendations concerning other business characteristics are made that may further refine the result of the methodological approach used.

The discounted cash flow measurement method itself-which calculates the net present value-and the continuing value of FCFE undoubtedly have certain limitations, inter alia due to the use of a single discount rate. This is caused by the fact that the continuing FCFE value is calculated using an infinite annuity [1]. Even when using more than one factor with more than one discount rate, it is generally not possible to include the effects of changing debt ratios, increasing project capitalization, trends in return on equity towards a risk-free rate, or offsetting technical risks. A change in the capital structure is not expected for the selected company. Although the current structure of the company is considered to be rather conservative (i.e., it reduces the potential profit of the company), it is nevertheless one that allows the risk of the financial structure to be kept to a minimum. The capital structure of the company affects the value of the whole company. This is the right balance between equity and debt so that the positive effect of leverage is maintained. In public limited companies, the capital structure of a company is thus reflected in the value of the shares held by individual shareholders. Therefore, the shareholders who make decisions about the composition of the company's capital should focus on its correct composition [78]. A positive leverage effect can increase a company's value in the process of valuation [79]. Cheng, Liu, and Chien [80] have, therefore, developed a model to determine the maximum possible level of external financing of a company that no longer increases its value.

On the other hand, Kopecky et al. [81] developed a model of an alternative equilibration process, where there is a partial balance of debt with recapitalization costs and where the optimal capital structure of the company is clearly not set, even in the absence of any interaction between debt and other aspects of corporate decision-making. According to these conclusions, therefore, this does not necessarily mean that the value of the shares of a company with low leverage will be low. Companies using foreign capital will thus have to think about whether it is not necessary to restructure the company's capital structure or at least refinance the loans used. However, from the point of view of a company with a stable ownership structure and stable financing, the model used is clearly suitable, as evidenced by demonstrable results. The benefits lie in the time factor, the applicability of this model to any company, and a great data transparency.

The development of the economy (GDP growth) is a prerequisite for the analysis of the continuing values of the FCFE, but for future calculations, it is also possible to consider the development of inflation. For further investigation, a comparison of the intrinsic value of a stock with the market price of a stock may be interesting. This will determine if the stock is overvalued or undervalued. Another interesting issue worth further examining may be a comparison of the resulting value of FCFE, which expresses the intrinsic value of the company from the perspective of the shareholder, with the value of Free Cash Flow to the Firm (FCFF), which expresses the intrinsic value from the perspective of the entire company. 
Author Contributions: Conceptualization, V.J.; methodology, V.J. and Z.R.; software, Z.R. and V.M; validation, Z.R., V.M., and J.H.; formal analysis, V.M. and J.H.; investigation, V.J. and Z.R.; resources, V.M. and J.H.; data curation, V.J. and Z.R.; writing-original draft preparation, V.J. and Z.R.; writing-review and editing, V.M. and J.H.; supervision, J.H.; project administration, V.M. All authors have read and agree to the published version of the manuscript.

Funding: This research received no external funding.

Conflicts of Interest: The authors declare no conflict of interest.

\section{References}

1. Magni, C.A. Investment Decisions and the Logic of Valuation. Linking Finance, Accounting, and Engineering; Springer Nature: Cham, Switzerland, 2020.

2. Government of the Czech Republic. Act No. 563 of 31 December 1991 on Accounting. In Collection of Laws of the Czech Republic; Government of the Czech Republic: Prague, Czech Republic, 1991.

3. Papanastasopoulos, G.; Thomakos, D. Managerial discretion, net operating assets and the cross-section of stock returns: Evidence from European countries. J. Int. Financ. Mark. Inst. Money 2017, 47, 188-210. [CrossRef]

4. Penman, S.H.; Yehuda, A. Matter of principle: Accounting reports convey both cash-flow news and discount-rate news. Manag. Sci. 2019, 65, 5584-5602. [CrossRef]

5. Koller, T.; Geodhart, M.; Wessels, D. Valuation: Measuring and Managing the Value of Companies, 5th ed.; John Wiley \& Sons, Inc.: Hoboken, NJ, USA, 2010.

6. Estridge, J.; Lougee, B. Measuring free cash flows for equity valuation: Pitfalls and possible solutions. J. Appl. Corp. Finance 2007, 19, 60-71. [CrossRef]

7. Mielcarz, P.; Mlinarič, F. The superiority of FCFF over EVA and FCFE in capital budgeting. Econ. Res. Ekon. Istraž. 2014, 27, 559-572. [CrossRef]

8. Brealey, R.A.; Myers, S.C.; Allen, F. Principles of Corporate Finance, 13th ed.; McGraw-Hill: New York, NY, USA, 2019.

9. Petřík, T. Economic and Financial Management of the Company: Managerial Accounting in Practice, 2nd ed.; Grada: Prague, Chech Republic, 2009.

10. Veselá, J. Investing in Capital Markets; Wolters Kluwer: Prague, Chech Republic, 2011.

11. Pimonenko, T.; Bilan, Y.; Horák, J.; Starchenko, L.; Gajda, W. Green brand of companies and greenwashing under sustainable development goals. Sustainability 2020, 12, 1679. [CrossRef]

12. Zurita, S.; Castillo, A.; Niño, J. Inflation, tax integration and company valuation: The Latin American case. J. Bus. Res. 2019, 105, 370-380. [CrossRef]

13. Westfall, T.J.; Omer, T.C. The emerging growth company status on IPO: Auditor effort, valuation, and underpricing. J. Account. Public Policy 2018, 37, 315-334. [CrossRef]

14. Kasych, A.; Vochozka, M.; Yakovenko, Y. Diagnostics of the stability states of enterprises and the limits of their tolerance. Qual. Access Success 2019, 20, 3-12.

15. Müller, J.M.; Buliga, O.; Voigt, K. Fortune favors the prepared: How SMEs approach business model innovations in Industry 4.0. Technol. Forecast. Soc. Chang. 2018, 132, 2-17. [CrossRef]

16. Gray-Hawkins, M.; Michálková, L.; Šuleř, P.; Zhuravleva, N.A. Real-time process monitoring in Industry 4.0 manufacturing systems: Sensing, smart, and sustainable technologies. Econ. Manag. Financ. Mark. 2019, 14, 30-36. [CrossRef]

17. Dagnino, G.B.; Giachetti, C.; La Rocca, M.; Picone, P.M. Behind the curtain of international diversification: An agency theory perspective. Glob. Strat. J. 2019, 9, 555-594. [CrossRef]

18. Anwer, E.; Deshpande, S.; Derry, R.; Basil, D.S. The value of values in business purchase decisions. J. Bus. Ind. Mark. 2020. [CrossRef]

19. To, C.K.M.; Chau, H.P.; Kan, W. The logic of innovative value proposition: A schema for characterizing and predicting business model evolution. J. Bus. Res. 2020, 112, 502-520. [CrossRef]

20. Lange, G.S.; Johnston, W.J. The value of business accelerators and incubators-An entrepreneur's perspective. J. Bus. Ind. Mark. 2020. [CrossRef]

21. Conboy, K.; Dennehy, K.; O'Connor, M. 'Big time': An examination of temporal complexity and business value in analytics. Inf. Manag. 2020, 57. [CrossRef] 
22. Stehel, V.; Hejda, J.; Vochozka, M. Use of objectivized value in business valuation. AD ALTA J. Interdiscip. Res. 2019, 9, 333-338.

23. Vrbka, J. The use of neural networks to determine value based drivers for SMEs operating in the rural areas of the Czech Republic. Oecon. Copernic. 2020, 11, 325-346. [CrossRef]

24. Cepel, M.; Dvorský, J.; Gregová, E.; Vrbka, J. Business environment quality model in the SME segment. Transform. Bus. Econ. 2020, 19, 262-283.

25. Cui, L.; Chan, H.K.; Zhou, Y.; Dai, J.; Lim, J.J. Exploring critical factors of green business failure based on Grey-Decision Making Trial and Evaluation Laboratory (DEMATEL). J. Bus. Res. 2019, 98, 450-461. [CrossRef]

26. Spieth, P.; Schneider, S.; Clauss, T.; Eichenberg, D. Value drivers of social businesses: A business model perspective. Long Range Plan. 2019, 52, 427-444. [CrossRef]

27. Dong, J.Q.; Yang, C. Business value of big data analytics: A systems-theoretic approach and empirical test. Inf. Manag. 2020, 57. [CrossRef]

28. Zhang, H.; Gupta, S.; Sun, W.; Zou, Y. How social-media-enabled co-creation between customers and the firm drives business value? The perspective of organizational learning and social Capital. Inf. Manag. 2020, 57. [CrossRef]

29. Dong, Q.; Wen, S.; Liu, X. Credit Allocation, Pollution, and sustainable growth: Theory and evidence from China. Emerg. Mark. Finance Trade 2020, 51, 2793-2811. [CrossRef]

30. Tiba, S.; Frikha, M. EKC and macroeconomics aspects of well-being: A critical vision for a sustainable future. J. Knowl. Econ. 2020, 11, 1171-1197. [CrossRef]

31. Kasych, A.; Vochozka, M. Methodical support of the enterprise sustainable development management. Mark. Manag. Innov. 2018, 1, 371-381. [CrossRef]

32. Kuo, C. Does the vector error correction model perform better than others in forecasting stock price? An application of residual income valuation theory. Econ. Model. 2016, 52, 772-789. [CrossRef]

33. Davies, S.P.; Johnson, L.E.; Lowensohn, S. Ambient influences on municipal net assets: Evidence from panel data. Contemp. Account. Res. 2017, 34, 1156-1177. [CrossRef]

34. Erauskin, I.; Gardeazabal, J. The terms of trade, the external balance, and the size of the net foreign asset position. Int. Rev. Econ. Finance 2017, 50, 245-260. [CrossRef]

35. Dotzel, T.; Shankar, V. The relative effects of business-to-business (vs. business-to-consumer) service innovations on firm value and firm risk: An empirical analysis. J. Mark. 2019, 83, 133-152. [CrossRef]

36. Chang, C.T.; Ouyang, L.; Teng, J.; Lai, K.; Cárdenas-Barrón, L.E. Manufacturer's pricing and lot-sizing decisions for perishable goods under various payment terms by a discounted cash flow analysis. Int. J. Prod. Econ. 2019, 218, 83-95. [CrossRef]

37. Lilford, E.; Maybee, B.; Packey, D. Cost of capital and discount rates in cash flow valuations for resources projects. Resour. Policy 2018, 59, 525-531. [CrossRef]

38. Nikoofal, A.; Bagheri, M.; Assadi, M. Multiobjective model for solving resource-leveling problem with discounted cash flows. Int. Trans. Oper. Res. 2018, 25, 2009-2030. [CrossRef]

39. Bian, Y.; Lemoine, D.; Yeung, T.G.; Bostel, N.; Hovelaque, V.; Viviani, J.L.; Gayraud, F. A dynamic lot-sizing-based profit maximization discounted cash flow model considering working capital requirement financing cost with infinite production capacity. Int. J. Prod. Econ. 2018, 196, 319-332. [CrossRef]

40. Li, R.; Chan, Y.; Chang, C.T.; Cárdenas-Barrón, L.E. Pricing and lot-sizing policies for perishable products with advance-cash-credit payments by a discounted cash-flow analysis. Int. J. Prod. Econ. 2017, 193, 578-589. [CrossRef]

41. Pless, J.; Douglas, J.; Arent, J.; Logan, J.; Cochran, J.; Zinaman, O. Quantifying the value of investing in distributed natural gas and renewable electricity systems as complements: Applications of discounted cash flow and real options analysis with stochastic inputs. Energy Policy 2016, 97, 378-390. [CrossRef]

42. Drobetz, W.; Janzen, M.; Meier, I. Investment and financing decisions of private and public firms. J. Bus. Finance Account. 2019, 46, 225-262. [CrossRef]

43. Rodríguez López, Á.; Rubio, M. The marketability discount in Spanish valuation multiples: Investors' perception in listed companies versus private transactions. J. Bus. Econ. Manag. 2019, 20, 107-130. [CrossRef]

44. Tsuji, M.; Fukunaga, K. Judgments on firm valuation in Japan. Acad. Account. Financ. Stud. J. 2018, $22,1-11$. 
45. Prusak, B. The accuracy of alternative stock valuation methods-The case of the Warsaw Stock Exchange. Econ. Res. Ekon. Istraž. 2017, 30, 416-438. [CrossRef]

46. Turcas, F.; Dumiter, P.; Boita, M. Forecasting, valuation and portfolio returns of stock market evolution: Problems, paradoxes and efficient information. Worldwide Implications and Romanian Evidence. J. Bus. Econ. Manag. 2020, 21, 87-114. [CrossRef]

47. Jin, Z.; Navare, J.; Lynch, R. The relationship between Innovation culture and Innovation outcomes: Exploring the effects of sustainability orientation and firm size. R D Manag. 2019, 49, 607-623. [CrossRef]

48. Bodhanwala, S.; Bodhanwala, R. Does corporate sustainability impact firm profitability? Evidence from India. Manag. Decis. 2018, 56, 1734-1747. [CrossRef]

49. Sroufe, R.; Gopalakrishna-Remani, V. Management, social sustainability, reputation, and financial performance relationships: An empirical examination of US firms. Organ. Environ. 2019, 32, 331-362. [CrossRef]

50. Jackowicz, K.; Mielcarz, P.; Wnuczak, P. Fair value, equity cash flow and project finance valuation: Ambiguities and a solution. Manag. Finance 2017, 43, 914-927. [CrossRef]

51. Almabekova, O.; Kuzmmich, R.; Antosik, E. Income approach to business valuation: Russian perspective. Int. Rev. Econ. Bus. 2018, 21, 115-128. [CrossRef]

52. Toll, C.; Hering, T. Valuation of company from the shareholders' point of view. Amfiteatru Econ. 2017, 19, 836-852.

53. Lorenc, L.; Kustra, A. Financial liquidity management in energy sector in Poland. IOP Conf. Ser. Earth Environ. Sci. 2019, 214. [CrossRef]

54. Suhanda, N.H.; Hidayat, A.N.; Firmansyah, A. Firm value and performances in merger policy: Evidence from Indonesia. Acad. Account. Financ. Stud. J. 2019, 23, 1-12.

55. Serrano, A.; Oliva, R.; Kraiseburd, S. On the cost of capital in inventory models with deterministic demand. Int. J. Prod. Econ. 2017, 183, 14-20. [CrossRef]

56. Sarwar, B.; Ming, X.; Husnain, M. Economic policy uncertainty and dividend sustainability: New insight from emerging equity market of China. Econ. Res. Ekon. Istraž. 2020, 33, 204-223. [CrossRef]

57. Badenhorst, W.M. Tax preferences, dividends and lobbying for maximum value. S. Afr. J. Econ. Manag. Sci. 2017, 20. [CrossRef]

58. Nekhili, M.; Amar, I.F.B.; Chtioui, T.; Lakhal, F. Free cash flow and earnings management: The moderating role of governance and ownership. J. Appl. Bus. Res. 2016, 32, 255-268. [CrossRef]

59. Nobanee, H.; Abraham, J. The impact of free cash flow, equity concentration and agency costs on firm's profitability. Invest. Manag. Financ. Innov. 2017, 14, 19-26. [CrossRef]

60. Bonazzi, G.; Iotti, M. An analysis of the annual accounts of highway firms in Italy applying a comparative approach through income and financial margins assessments. Res. J. Appl. Sci. 2016, 11, 267-280.

61. Nozari, A. The impact of financial leverage on agency cost of free cash flows in listed manufacturing firms of Tehran stock exchange. Turk. Online J. Des. Art Commun. 2016, 6, 1920-1927. [CrossRef]

62. Georgios, P.N.; Chris, G. Employing valuation tools for public and private companies. The food sector in Greece. In Proceeding of the Economies of Balkan and Eastern Europe Countries in the Changed World, Kavala, Greece, 8-10 May 2015; Karasavvoglou, A.G., Kyrkilis, D., Polychronidou, P., Eds.; Elsevier: Amsterdam, The Netherlands, 2015.

63. Ahdizia, K. Business valuation of Islamic banks in the merger plan to become Indonesia's state-owned bank. Etikonomi J. Ekon. 2018, 17, 223-236. [CrossRef]

64. Li, Z.; Minor, D.B.; Wang, J.; Yu, C. A learning curve of the market: Chasing alpha of socially responsible firms. J. Econ. Dyn. Control 2019, 109. [CrossRef]

65. Usman, B. CSR performance firm's attributes, and sustainability reporting. Int. J. Bus. Soc. 2020, 21, 521-539.

66. Li, F.; Morris, T.; Young, B. The effect of corporate visibility on corporate social responsibility. Sustainability 2019, 11, 3698. [CrossRef]

67. Hur, W.M.; Moon, T.W.; Kim, H. When and how does customer engagement in CSR initiatives lead to grater CSR participation? The role of CSR credibility and customer-company identification. Corp. Soc. Responsib. Environ. Manag. 2020, 27, 1878-1891. [CrossRef]

68. Lee, S.Y.; Zhang, W.W.; Abitbol, A. What makes CSR communication lead to CSR participation? Testing the mediating effects of CSR associations, CSR credibility, and organization-public relationships. J. Bus. Ethics 2019, 157, 413-429. [CrossRef]

69. Beck, C.; Frost, G.; Jones, S. CSR disclosure and financial performance revisited: A cross-country analysis. Austral. J. Manag. 2018, 43, 517-537. [CrossRef] 
70. Vochozka, M.; Stehel, V.; Rowland, Z. Determining development of business value over time with the identification of factors. AD ALTA J. Interdiscip. Res. 2019, 9, 358-363.

71. Morri, G.; Artegiani, A. The effects of the global financial crisis on the capital structure of EPRA/NAREIT Europe index companies. J. Eur. Real Estate Res. 2015, 8, 3-23. [CrossRef]

72. Li, S.; Yu, Z.; Song, H. The improved business valuation model for RFID company based on the community mining method. PLoS ONE 2017, 12. [CrossRef]

73. Misund, B.; Nygård, R. Big fish: Valuation of the world's largest salmon farming companies. Marine Resour. Econ. 2018, 33, 245-261. [CrossRef]

74. Loyarte-López, E.; Barral, M.; Morla, J.C. Methodology for carbon footprint calculation towards sustainable innovation in intangible assets. Sustainability 2020, 12, 1629. [CrossRef]

75. Thum-Thysen, A.; Voigt, P.; Bilbao-Osorio, B.; Maier, C.; Ognyanova, D. Investment dynamics in Europe: Distinct drivers and barriers for investing in intangible versus tangible assets? Struct. Chang. Econ. Dyn. 2019, 51, 77-88. [CrossRef]

76. Tarifa-Fernández, J.; Sánchez-Pérez, A.M.; Cruz-Rambaud, S. Internet of things and their coming perspectives: A real options approach. Sustainability 2019, 11,3178. [CrossRef]

77. Kasych, A.; Vochozka, M. The choice of methodological approaches to the estimation of enterprise value in terms of management system goals. Qual. Access Success 2019, 20, 3-9.

78. Venugopal, M.; Sharma, G.B.P.; Reddy, M.R. Impact of capital structure on shareholder value in Indian pharmaceutical industry: An empirical approach through created shareholder value. Glob. Bus. Rev. 2018, 19, 1290-1302. [CrossRef]

79. Singh, K.; Hodder, J.E. Multinational capital structure and financial flexibility. J. Int. Money Finance 2000, 19, 853-884. [CrossRef]

80. Cheng, Y.S.; Liu, Y.P.; Chien, C.Y. Capital structure and firm value in China: A panel threshold regression analysis. Afr. J. Bus. Manag. 2010, 4, 2500-2507.

81. Kopecky, K.J.; Li, Z.; Sugre, T.F.; Tucker, A.L. Revisiting M\&M with taxes: An alternative equilibrating process. Int. J. Financ. Stud. 2018, 6, 10. [CrossRef]

Publisher's Note: MDPI stays neutral with regard to jurisdictional claims in published maps and institutional affiliations.

(C) 2020 by the authors. Licensee MDPI, Basel, Switzerland. This article is an open access article distributed under the terms and conditions of the Creative Commons Attribution (CC BY) license (http://creativecommons.org/licenses/by/4.0/). 